\title{
Hard-Boiled Ecologies: Ross Macdonald's Environmental Crime Fiction
}

Author of eighteen novels and three collections of short stories featuring the acerbic, tough talking private-eye Lew Archer, Ross Macdonald's position in the annals of great American hardboiled crime writers is unquestioned. Macdonald's texts provide an equally unflinching glimpse into the violence and depravity of post-war California's criminal underworld, continuing the tradition of the cynical, urban crime novel popularised by writers such as Raymond Chandler and Dashiell Hammett. Punctuated with narratives of domestic crime, childhood trauma, and ancestral dysfunction, Macdonald's oeuvre offers a bleak vision of American suburbia, one built upon intergenerational violence, oedipal drama and corporate exploitation. Whilst Macdonald's connection to the traditions of the American hardboiled has been thoroughly examined, what has often been overlooked in the study of his work are the underlying environmental preoccupations that frequently serve as the background to, or context for, crime. This convergence between ecology and criminality takes on greater significance when read in the context of Macdonald's own involvement in environmental activism. A leading member of the Santa Barbara Citizens for Environmental Defence, in the late 1950s Macdonald became deeply concerned with the damage being inflicted upon Santa Barbara's delicate coastal wildlife by the influx of oil-well platforms. Following the eventual eruption of one of these platforms in 1969, Macdonald wrote and campaigned passionately for a "new politics of ecology', one that expressed the public's bourgeoning 'moral and economic doubts about the American uses of energy' (Macdonald 1998, 326).

This context of ecological violence is forcefully manifested in two of Macdonald's later Archer novels; The Underground Man (1971) and Sleeping Beauty (1973). Featuring an uncontrollable forest fire and a contaminating oil spill respectively, The Underground Man and Sleeping Beauty present ecological disaster as an adjunct to human depravity and violence. As 
such, this article argues that the damage and destruction inflicted upon the environment in these texts becomes symbiotically connected to the morally fraught social milieu of the city. Through the vehicle of the crime novel, Macdonald establishes a correlation between "nature and human nature", as 'the harm done to the fragile ecology' ultimately materialises as the "consequence of, and counterpart to, violations inflicted on other people" (Fine 2000, 132). This becomes most explicitly dramatised in the theme of spoiled innocence, specifically in the parallel Macdonald draws between the damage inflicted upon delicate ecologies by a combination of corporate greed and human irresponsibility and the harm exacted upon children by equally selfserving and negligent parents. Within this, Macdonald's work expresses a tension central to the American pastoral: the longing for an idyllic landscape that is always in the process of disappearing.

\section{Pollution and Environment in the Hardboiled Crime Novel}

American crime fiction has a long tradition of presenting warped families and abhorrent criminal acts as a symptom of a broader pattern of cultural and environmental decline. In the decaying and adulterated urban setting, the hardboiled detective typically attempts to combat this entrenched and pernicious culture of corruption, even whilst it is perpetuated by the very institutions and mechanisms designed to eradicate it. Although ecocritical readings of hardboiled crime fiction are somewhat limited, many critics have acknowledged the genre's enduring preoccupation with ideas of pollution and contamination. The sprawling metropolis is frequently rendered as a "polluted wasteland", one that threatens to "poison and corrupt" anyone who walks its mean streets, even the private eye himself (Scaggs 2005, 70). Scaggs points to Dashiell Hammett's Red Harvest as a novel that prefigures this connection between crime, contamination and the urban environment. After being called to the aptly name Poisonville to investigate the murder of newspaper publisher Donald Willsson, the Continental 
Op begins to sense that he is being slowly soiled by the violence and depravity of the city. 'It's this damned town", he tells Dinah Brand, 'Poisonville is right. It's poisoned me' (Hammett 2003, 156). As Scaggs suggests, the Continental Op's fears of infection appear vindicated when he awakens the next morning holding an ice pick, the sharp end of which has been plunged into the chest of the prostrate Dinah Brand.

Scaggs also cites Raymond Chandler's The Big Sleep as a text that exhibits similar anxieties about the polluted physical and moral topography of the city. As Marlowe gets drawn deeper into the sordid secrets of the Sternwood family, he too senses that he has become infected by the "nastiness" of the city (Chandler 2011, 250). Yet Chandler's novel also examines a larger union between environmental pollution and the fraught cultural landscape of Southern California, most obviously through General Sternwood's connection to the oil industry. There are several descriptions in the text of the decaying oil wells where the Sternwood's made their fortune, a rotten wasteland of "stagnant, oil-scummed water", "rusted metal" and sagging structures $(237,242)$. Located outside of the city, these images of corrosion and despoliation emphasise the text's examination of the connection between urban expansion, criminality and pastoral devastation. Sarah Trott focuses on several instances in Chandler's work which emphasise a stark conflict between the "pastoral and the urban", a tradition that she argues has captured the imagination of numerous American writers across genres (2016, 102). She perceives Marlowe's attempts to escape the "frenzied urban landscape" to the "peaceful pastoral" in Lady in the Lake and Playback as indicative of a broader "literary cry against the waves of dehumanizing modernity sweeping through the United states in the early twentieth century" (102).

In The Lay of the Land, Annette Kolodny describes this 'pastoral impulse' as something unique to the American consciousness, principally because the "entire process" of frontier expansion remains within "historical memory" (1975, 8). For Kolodny, this gives Americans 
the ability to "see themselves as the wilful exploiters of the very land that had once promised an escape from such necessities" (8). Thus, not only is the "pastoral impulse neither terminated or wholly repressed", but the entire "dream and its betrayal, and the consequent guilt and anger" remain potent and corrosive forces in the American psyche (8). The inherent tensions and ambiguities surrounding the "American pastoral"-I argue - are underexplored yet key facets in Macdonald's work and American hardboiled crime fiction more generally (Garrard 2012, 54). Both The Underground Man and Sleeping Beauty not only elucidate this tension between rapid industrial development and the pastoral myth, but also are inundated with characters who possess a profound sense of loss and guilt. This guilt - often manifested in the spoiled innocence of youth - becomes intimately intertwined with a broader corrosion of the pastoral idyll.

Indeed, the destructive effects of corporate consumption and environmental exploitation are recurring themes that can be traced throughout all the Archer novels. In multiple guises, Macdonald presents an urban topography saturated by a rigid and violent form of individualism, one that has a detrimental impact on the fragile balance of families, societies and ecosystems. As Robert Gale suggests, the overriding message of Macdonald's writings is "that greed damages the environment, corrupts legitimate commercial enterprises, and-worst of all—wrecks loving human relationships" (2002 xi). One need only look at the second Archer novel, The Drowning Pool (1950), to gauge the ultimate trajectory of his work. Prefiguring Macdonald's fixation with the stark disconnect between corporate power and environmental responsibility, The Drowning Pool revolves around the Pareco Oil Company's attempts to purchase the land of wealthy matriarch Olivia Slocum, whose rural estate sits on top of a lucrative oil reservoir. Despite pressure from her destitute and financially dependent son James, Olivia Slocum refuses to sell the property, seemingly due to the potentially damaging environmental consequences. In truth, Slocum's motives are more racially and aesthetically 
driven than environmentally, as this feigned ecological concern disguises her real motive: 'that of keeping out the Mexicans and dirty oil-crew workers who damage the town's prestige" (Weinkauf 1994, 87).

Although the Slocums' ultimate indifference towards environmental ethics becomes clear as the narrative progresses, Macdonald's own anxieties regarding the rapid devastation of post-war California's rural spaces are rendered palpable via Archer's potent description of Nopal Valley's desolate and festering landscape:

The oil wells from which the sulphur gas rose crowded the slopes on both sides of the town. I could see them from the highway as I drove in: the latticed triangles of the derricks where trees had grown, the oil-pumps nodding and clanking where cattle had grazed. Since 'thirty-nine or 'forty, when I had seen it last, the town had grown enormously, like a tumour. The main street had been transformed by glass brick, plastic, neon. (25)

Archer provides an almost post-apocalyptic vision of a decaying wasteland forged by the joint ventures of industrial expansion and land development. Broadening exponentially, the economic imperatives of capitalism are depicted as a destructive and cancerous growth, a "tumour" whose malignant tendrils metastasize violently across the rural landscape, devouring, destroying and leaving in their wake a barren wilderness of skeletal wildlife and acrid, carcinogenic smog. The city is the rotting corpse beneath the spectacle of glass brick and pulsating neon, the erstwhile natural entities of trees and cattle are erased and replaced by the polluted signs of an unstoppable and pervasive consumerism. Situated directly before Archer's first visit to the Slocum residence, there is an element of foreboding in this desolate image of 
ecological decline, one that is eventually mirrored in the equally contaminated dynamic of the family.

After Olivia Slocum is discovered drowned in her pool, Archer unearths a festering maelstrom of betrayal, dishonesty and murder, a plot that implicates three generations of the Slocum family and leaves two women dead. Like the poisoned and desolate topography of the city, by the denouement both "the family and the family place" have been equally and irreparably "corrupted" (Moore 2006, 262). The familial dynamic becomes inseparable from the corporate logic of the city, one that prioritises ruthless exploitation and greed over cooperation, community and coexistence. The moral thrust of The Drowning Pool becomes demonstrably clear, as it is the Slocum family's failure to "recognise and nurture" relationships, be they "ecological or familial in nature", that ultimately catalyses such widespread disaffection and death (Witschi 2014, 386). Outside of Olivia Slocum's murder, drowning proves a powerful central motif, signifying the family's symbolic submersion in bottomless depths of greed and deception. Yet water itself emerges a source of potential purification, an idyllic entity that cannot be tarnished by Southern California's toxic milieu. In a tranquil moment when Archer cleanses his befouled psyche in the "long blue space" of the Pacific Ocean, he takes solace in the incorruptibility of the water. Peering out at the "jerrybuilt beaches" and "superhighways" that have demolished and replaced "thousands of years of redwood growth", Archer still perceives the vast expanse of the ocean as impervious to the contamination of anthropogenic pollutants. Ruminating on the rapid devastation of Southern California's pastoral landscape, he hopefully asserts: “They couldn't touch the ocean. They poured their sewage into it, but it couldn't be tainted" (23).

This juxtaposition of California's stark yet waning physical beauty with its vacuous and violent social milieu is very much a reflection of Macdonald's own tempestuous and wavering relationship with his adopted Santa Barbara home. As pessimistic as Macdonald was about the 
Santa Barbara "cultural climate", he found a certain solace in its natural tranquillity and beauty, particularly the "mind calming, soul-cleansing sea" (Nolan 1999, 282). The erection of a number of Oil Well platforms off the Santa Barbara coast in the late 1950's was therefore a source of great irritation and concern for Macdonald. He was a frequent and vocal detractor, publicly denouncing Union Oil and the U.S. Department of Interior for conspiring to sanction illegal drilling in the channel without the requisite legal surveys and precautions.

His growing frustration at such blatant political disregard towards matters of conservation was further exacerbated in 1964, when Macdonald became heavily involved in a battle to prevent the building of a new road near the Los Padres National Forest. An avid bird watcher, Macdonald was particularly concerned about the habitat of the near extinct California condor. The woodland had previously acted as an unofficial sanctuary for the endangered bird and he feared that increased human intrusion would have a detrimental impact on its conservation. Macdonald campaigned avidly to prevent the proposed developments, imploring fellow writers and friends to speak out against what he perceived as a moral injustice (Nolan 1999, 241). Macdonald's protests began attracting considerable publicity, so much so that the U.S Forest Service eventually agreed to hold a public hearing to allow the people of Santa Barbara the chance to decide the future fate of the road, one that ended in stalemate and a delay of the plans.

If this could be considered a small victory for Macdonald, then any optimism he might have harboured about the emergence of a more environmentally cognisant industrial and political agenda was severely dented by the underwater eruption of Union Oil's Platform A in February 1969. Within a matter of days, millions of gallons of crude oil and noxious gases spewed into the ocean, thickening into a slick that stretched over 600 miles across the city's coastline. Swept on uncontrollably by tides and waves, the oil continued to flow for months, inflicting catastrophic damage on the channel's coastal wildlife. Causing the death of thousands 
of birds, aquatic mammals and other fragile fauna, the oil spill was an environmental disaster on an unprecedented scale (Campbell 2008, 341). Describing the event as the "blowout heard around the world", Macdonald and wife Margaret once again spearheaded protests against oil drilling on the Santa Barbara coast (Macdonald 1998, 326). Although Macdonald had written, and continued to write, investigative and polemical pieces regarding the need for greater levels of ecological awareness and intervention, it was this event that prompted his explicit movement into environmental fiction. Described by Macdonald as "subject matter books", both The Underground Man (1971) and Sleeping Beauty (1973) signalled a new phase in the Archer novels, one that shifted the latent environmental anxieties of his previous texts to the narrative forefront (Nelson \& Avery 2016, 124).

\section{Innocence Lost: The Underground Man and Sleeping Beauty}

The Underground Man offers a warped and cynical vision of the California dream, one in which instances of familial disintegration and corrupted youth become brutally projected against the cataclysmic destruction of California's rural landscape. In the process, Macdonald presents us with an older and more jaded Archer, who in excavating the hidden secrets of damaged and destructive families, is confronted with his own equally disconnected existence. The novel opens with what Michael Kreyling $(2005,140)$ describes as "a strong premonition of disaster", as the sleeping Archer is woken an ominous "rattle of leaves" and stifling flow of "hot wind" through his open bedroom window (Macdonald 1971, 7). Archer's immediate exposure to the heat and decay of a "slightly used West Los Angeles" generates a portentous atmosphere of impending social and environmental ruin, a foreboding that is further compounded when he observes the sickly discolouration of the morning sky, its perforated edges stained with a "yellowish tinge like cheap paper darkening at the edges" (7). 
This veil of apocalyptic anxiety is momentarily lifted when Archer meets Ronny Broadhurst, an inquisitive and solitary young boy from one of the downstairs apartments. After a hesitant approach, the boy proceeds to help Archer feed a group of scrub jays that have nested in the courtyard of the apartment block. Birds have long been a feature of Macdonald's novels and the symbolism here is unambiguous. Macdonald foregrounds the moral undertones of the text via this symbiotic cohabitation between nature and humanity, whilst simultaneously drawing a forceful correlation between the vulnerability of the boy and the corresponding fragility of the birds. The relative tranquillity of the scene is soon ruptured by the manic energy of Ronny's father, Stanley, a man in his twenties who appears to Archer like "a grown-up version of the boy" with the same "impression of anxiety" (8). After bursting into the apartment courtyard and accusing his estranged wife of infidelity, Stanley whisks his son away to Santa Theresa, the home of the Broadhurst family and the site of a lucrative real estate development. Like his marriage, Stanley's volatile psyche is also in the process of fracturing. Obsessed with the quest to find his own father who mysteriously disappeared when he was a boy, this Freudian theme of parental absence is ironically duplicated via Stanley's similar neglect of his own son Ronny. Persistent in the belief that this loss "robbed his life of its meaning" (21), ironically it is Stanley's search itself that exacerbates the splintering of his already tortured subjectivity. It is unsurprising when Stanley's wife, Jean Broadhurst, appears at Archer's apartment later the same afternoon, expressing concern that she has not heard from either Stanley or Ronny. Her anxiety is further compounded by news of a vicious forest fire sweeping its away across the Santa Theresa hills.

Archer and Jean Broadhurst proceed to search for Stanley at the home of his mother, Mrs Broadhurst, the owner of the lucrative Canyon Estates development. Their approach to the estate unmistakeably emphasises the sordid conjunction between land development, warped family histories and environmental ruin. Like the Drowning Pool, the once untainted pastoral 
landscape has been divided up and swallowed by wealthy suburban homes, the repercussions of which are vividly portended in images of fire, decay and impending combustion:

The Broadhurst ranch lay between these houses and the fire. ... Her private asphalt lane wound through acres of mature avocado trees. Their broad leaves were shrivelling and the tips as if the fire had already reached them, darkening fruit hung down from their branches like hand grenades (32).

Macdonald's depiction of looming ecological catastrophe possesses an almost biblical inevitability, a punishment for past transgressions. The customarily lush leaves of the avocado trees are sinisterly altered into gnarled and shrivelled husks as if already scorched by the intense heat of the blaze. The "darkening" of the fruit itself further accentuates this image of contamination and death, symbolising not only the despoliation of the landscape but also the depravity and corruption underlying both the Broadhurst family history and the Canyon Estates development itself. Having utilised the language of war prior to this passage when comparing the fire to the "flashes of heavy guns too far away to be heard", the convergence between the avocados and "hand grenades" operates to extend this metaphor of intense conflict, whilst also stressing the extent to which the environmental has been superseded by, and subsumed within, broader industrial and economic imperatives.

The tragic repercussions of violence, greed and irresponsibility are no more evident than in the dark history that culminates in the death of Stanley Broadhurst and the simultaneous instigation of the fire. Like in most of Macdonald's novels, it is the sins and transgressions of parents that are revisited upon their children, a theme that becomes powerfully manifested in the mutilation of the equally fragile mountain ecology. Unable to track down Stanley or Ronny at the ranch, Archer's search leads him to the family's mountain cabin, a large and weathered 
redwood structure stained red "as if it had been splashed with blood" (38). This ominous image of violence transpires to be hauntingly apt, as the cabin is soon revealed to be the site of two bloody murders and two burials, one historic, one recent. After finding Stanley Broadhurst's parked car, it is not long before Archer discovers the young man's "curled" and abandoned body. Struck over the head with a pick-axe and then dumped in a shallow grave near the wooded surroundings of the house, the incongruity of the corpse in this idyllic forest scene clearly signifies what Ralph Willett describes as "a disturbance within nature" (1996, 25). This sense of disturbance is further compounded when Archer determines that it was Stanley's dropped cigarillo that instigated the forest fire in the first place. Although ostensibly an act of negligence, on a larger level the fire emerges as a metaphor for the damage inflicted upon future generations by the careless and selfish acts or crimes of those in the past. As well as instigating the fire, Stanley's death acts as the catalyst for a series of escalating revelations that slowly unearth a fraught history of betrayal, infidelity and intergenerational conflict, one that implicates several interlocking families. This unravelling runs in tandem with the swelling ferocity and intensity of the fire, as Macdonald establishes a clear reciprocity between the ecological and the familial. In both cases, Macdonald demonstrates that acts of negligence and "human short-sightedness" invariably come with "harsh consequences", both social and environmental (Bryson 2010, 169).

With the young Ronny Broadhurst still missing, Archer's investigation leads him through a host of other fracturing families and it is not long before he links the boy's disappearance to disaffected teenagers Jerry Kilpatrick and Sue Crandall. Like the Broadhurst's, the Kilpatrick's have been similarly torn apart by dishonesty and furtive betrayals. After being abandoned by his mother as a child, Jerry has since been under the guardianship of his father Brian, a real estate developer who symbolises the entrenched corruption and greed of the city's corporate institutions. Disillusioned and angry at his father 
for losing his mother to Leo Broadhurst, Jerry strikes up a bond with Sue Crandall, another teenager who feels similarly alienated from her parents. The Crandalls are also implicated in the novel's complex intergenerational and interfamilial saga, representing another fractured household of "mismatched generations and mismatched DNA" (Kreyling 2005, 151).

Archer eventually traces the missing teenagers to the Santa Theresa Marina, but is knocked unconscious by Jerry Kilpatrick before he can rescue the 'kidnaped' Ronny from the fleeing vessel. Through his subsequent inquiries into the damaged family histories of the rogue adolescents, Archer is alerted to the existence of a stark generational divide and profound sense of guilt. This is aptly surmised when a desperate Brian Kilpatrick attempts to understand the motivations for his son's actions. Unable to do so, he asserts: "we're losing a whole generation. They're punishing us for bringing them into the world" (80). Yet Archer sees through this rhetoric and understands that it is the noxious tendrils of past transgressions that have polluted the lives of those in the present. He uses the language of contamination near the climax of the novel, when he eventually tracks the missing teenagers to the Bay Area of San Francisco. After talking Sue Crandall out of jumping from the Golden Gate Bridge, he identifies the kidnapping as an attempt to "rescue Ronny from the adult world" (219). He ruminates that both teenagers ultimately belong "to a generation whose elders had been poisoned, like the pelicans, with a kind of moral DDT that damaged the lives of their young" (212).

The ornithological metaphor reasserts the association between the tarnished innocence of youth and the destruction of nature. Crucially, the overwhelming sense of guilt that saturates the novel becomes reflective not only of failed guardianship, but of a larger betrayal of the pastoral impulse. Like the rogue adolescents that find themselves forced to the periphery of society, the destruction of the natural landscape pushes the pastoral idyll further and further to the margins. Terry Gifford describes this tension between the pastoral idyll and the repercussions of industrial development as key to the American experience of landscape, 
arguing that "the anti-pastoral is, in sense, built into the American pastoral" from its origins (2014, 25). Citing Leo Marx's, The Machine in the Garden, he describes how the pastoral myth is always bound by a counteractive force that "undermines the idyll" from within (25). This inherent tension between the "dream and its betrayal" is epitomised by Archer and the hardboiled detective novel more generally (Kolodny 8). Whilst Archer laments the destruction of the environment and loss of American innocence, he is still plugged into the technological and industrial mainframe of the city. Like Marlowe before him, Archer is continually drawn back to its dark ravages, a return that renders the pastoral an unattainable and ever receding fantasy.

After rescuing Ronny, Archer pieces together the fragmented and complex history of the murders. Although these revelations precipitate the further breakdown of multiple families, the novel ends on a more ambiguous and possibly conciliatory note. Following a downpour of heavy rains that vanquish the fire but, in the process, further destabilise the city's already delicate ecology, Archer evacuates Jean and Ronny from the approaching flash floods. Driving through the heavy rain - a sign of purification in the wake of the proceeding blaze of depravity and violent passions-Macdonald presents an almost complete pseudo-family unit. As Archer inwardly pleads that Ronny doesn't repeat the same mistakes as his father, Jean reaches behind and gently touches the detective's neck. Macdonald seems to be offering hope here-not only for Archer-but for a whole generation of young people suffering from the moral and ecological deficiencies of their elders. Yet, this sense of hope is simultaneously problematised by the resounding image of the automobile, the veritable machine in the garden. A symbol of the city and technological development more broadly, the ending to the The Underground Man not only signals the continuing threat to the natural environment, but also Archer's own guilt and complicity in this process. 
The guilt and latent impact of past transgressions is a theme that Macdonald revisits in his second environmental crime novel, Sleeping Beauty. The novel unambiguously interrogates Santa Barbara's disastrous, real-life oil spill, using ecological catastrophe to re-examine the relationship between California's physical and psychic landscapes. Yet, Sleeping Beauty is a different kind of novel to The Underground Man, particularly in terms of pacing. As Tom Nolan suggests, whereas the latter "dances along" frantically "like a wildfire", the former “oozes like the black tide, slow and inexorable" (329). Sleeping Beauty's stifling atmosphere of pollution and contamination magnifies Macdonald's nightmare vision of California to uncharted proportions, as evidenced in its potently apocalyptic opening.

Peering out of the aircraft window on his journey back from a vacation in Mexico, Archer is confronted with a seemingly endless vista of black, carcinogenic discharge spreading exponentially across the previously sapphire Pacific Point coastline. In the middle of the slick stands a jagged oil platform, protruding out of the water like "the metal handle of a dagger that had stabbed the world and made it spill black blood" (1). This violent image of a wounded earth gushing black blood has dual implications. It represents the literal damage exacted upon the environment by the economic primacies of industrial capitalism, and can simultaneously be interpreted as a symbol of the fetid and repressed family secrets that will soon bubble to the surface and contaminate the lives of others.

Archer avoids heading home to his Los Angeles apartment and instead drives straight to Pacific Point so that he can assess the damage of the spill in person. Met by a panoramic view of the "enormous slick spreading like premature night across the sea" (2), Archer proceeds to the beach where he encounters-alongside numerous "spectators"- a young woman cradling a contaminated and dying bird. 
The surf was rising sluggishly. A black bird with a sharp beak was struggling in it. The bird had orange-red eyes, which seemed to be burning with anger, but it was so fouled with oil that at first I didn't recognise it as a western grebe.

A woman in a white shirt and slacks waded in thigh-deep and picked it up, holding its head so that I wouldn't peck her. I could see as she came back toward me that she was a handsome young woman with dark eyes as angry as the bird's. (2)

In a near duplication of the opening scene from the Underground Man, Macdonald once again draws a clear confluence between the fragility of birds and the brittleness of youth. Like the befouled feathers of the grebe, the young woman's white shirt and slacks are slowly stained by the toxic surf, foregrounding the novel's broader narrative patterns of spoiled innocence. Her anguish at the eventual death of the bird and the more widescale destruction of coastal wildlife is, to a certain extent, rooted in a feeling of guilt and complicity. Archer soon learns that the woman is Laurel Rosso, the granddaughter of oil magnate William Lennox whose company is directly responsible for the blow out. Concerned for Laurel and sensing her vulnerability, Archer offers to drive her home to her husband, Thomas. This proceeds to be a more diffic ult venture than it first appears, as Laurel soon slips away from Archer's guardianship, stealing a bottle of sleeping pills from his bathroom cabinet in the process. Fearing Laurel may take her own life, Archer feels a responsibility to locate her.

Archer's search for Laurel soon finds him embroiled in the dark history of the Lennox family. Founded by William Lennox, the oil company is now overseen by Laurel's father Jack, an ambitious and secretive man who is keen to subsume full control of the business. Jack's efforts to supress the severity and scale of the spill are aided by Laurel's uncle and former naval captain Benjamin Somerville. Although ostensibly family and business partners, the two men are bound together by a terrible secret, an historical crime that dates back to their naval service 
during Second World War. In an instance of cyclicality typical of Macdonald's work, the catastrophic ecological disaster the two men face bares striking similarities to the original crime that joins them. Oil is the common denominator in both cases and shapes a larger framework of buried lies, concealed passions and terrible crimes that will return, erupt and contaminate both the Lennox family and the wider landscape of the city, literally and figuratively.

Like many of Macdonald's families, the Lennox dynasty and "its extensions balance the appearance of stability against the actuality of deep psychological fissures" (Kreyling 2005, 148). These hidden cracks, many of which are rooted in the traumas of the past, slowly begin to surface when the body of a scarred old man is discovered face down in the oily shallows of the surf. With "oil in his nostrils" and "oil in his mouth" (82), the polluted cadaver is emblematic of a city so dependent on the consumption of oil that it is literally drowning in it. Indeed, the suffocating residue of oil pervades the text, staining windows, polluting streets and assaulting the sight, smell and taste of those left trudging through the toxic waste of the spill. As much as the eruption becomes an allegory for a family stained by guilt and crime, the novel also interrogates the collective culpability of both the state of California and the nation at large. When freelance reporter Wilbur Cox enlightens Archer on the corporate gambling that directly precipitated the spill, he also blames the broader social milieu for its complicity in the upsurge of oil dependency. "They're not the only gamblers," he asserts, "we're all in the game. We all drive cars and we're all hooked on oil. The question is how can we get unhooked before we drown in the stuff' (112). Archer's sense of culpability is certainly palpable throughout the text. As Kreyling suggests, "mobility is a central part of Archer's identity" and his car is what facilitates his movement around the city (146). As he is drawn deeper and deeper into the violent turmoil of the Lennox family, Archer finds himself "wishing that [humans] could live like birds and move through nature without hurting it or ourselves" (124). Ironically, it is the automobile itself, and the very possibilities it offers, that catalyses a rare moment in the text 
where Archer feels "mobile and unencumbered" (86). Yet this feeling is short-lived, as Archer recognises that his vision of freedom and innocence is inherently corrupt. Like everybody else, he is a cog in the polluted machinery of the megalopolis, a trapped "citizen of the endless city" (86). Once again Archer incarnates the complex dialectic of the American pastoral, the irreconcilable bind between the condemnation of technology and its simultaneous embracement.

Like the UndergroundMan, Sleeping Beauty presents the tarnished foundations of the family as a symbol of a broader destruction of the pastoral idyll. The repressed sins of the Lennox family, sins that erupt and destroy the lives of those in the present, find their direct equivalence in the disastrous damage visited upon the environment by the similarly shortsighted plunder of natural resources. The oil-sodden body of the scarred man actualises this merging of familial and societal guilt. The witness to an historical murder that was the consequence of infidelities on the part of the both Jack Lennox and Captain Somerville, the dead man becomes the key to unlocking a feted history of betrayal and death. Although blame for the two murders ostensibly falls at the feet of Jack Lennox's disaffected and scorned wife Marian, the whole family are equally implicated in her crimes, reiterating Macdonald's emphasis on collective rather than individual guilt. At the book's close, Archer manages to return Laurel to her family, but cannot prevent Marian Lennox jumping from the balcony of her house down on to the jagged rocks below.

Like all of Macdonald's novels, The Underground Man and Sleeping Beauty offer a warped image of American suburbia built upon the fragile foundations of repressed crime and intergenerational struggle. Yet this article has argued that these two texts also mark an important shift in Macdonald's crime writing, bringing his previously latent ecological anxieties to the narrative forefront. Through the lens of the corrupt American family, both texts project ancestral dysfunction against the backdrop of shattering environmental devastation and, 
in the process, transmit an entrenched tension between nature and technological and industrial development. In this sense, The Underground Man and Sleeping Beauty bring a unique "environmental consciousness" to the hardboiled crime novel, using narratives of "industrial waste and urban pollution as symbols of the despoliation of the American landscape", both on a physical and psychic level (Casella 2011, 503). In doing so, they mark an important strand in the detective text, whilst simultaneously conforming Macdonald's status as one of the very earliest "ecological prophets" (Wagner Martin 2013, 154). The sociological and industrial scope of Macdonald's environmental crime fiction not only confirms his continued importance in the history of detective fiction, but opens up the potential for further examinations of how pollution and the environment have figured, and continue to figure, in the hardboiled novel.

\section{Bibliography}

Bryson, J. Scott. 2010. "Surf, Sagebrush and Cement Rivers: Reimagining Nature in Los Angeles." In The Cambridge Companion to the Literature of Los Angeles, edited by Kevin R. McNamara, 167-176. Cambridge: Cambridge University Press.

Campbell, Ballard. 2008. Disasters, Accidents, and Crises in American History: A Reference Guide to the Nation's Most Catastrophic Events. New York: Facts on File.

Casella, Donna R. 2001. "Macdonald, Ross." In The Guide to United States Popular Culture, edited by Ray Broadus Browne and Pat Browne, 503. Madison: University of Wisconsin Press.

Chandler, Raymond. 2011. The Big Sleep. London: Penguin.

Fine, David. 2000. Imagining Los Angeles: A City in Fiction. Las Vegas: University of Nevada Press. 
Gale, Robert L. 2002. A Ross MacDonald Companion. Westport: Greenwood Press.

Garrard, Greg. 2012. Ecocriticism. London: Routledge.

Gifford, Terry. 2014. "Pastoral, Anti-Pastoral and Post-Pastoral." In The Cambridge Companion to Literature and the Environment, edited by Louise Westling, 17-30. Cambridge: Cambridge University Press.

Hammett, Dashiell. 2003. Red Harvest. London: Orion.

Kolodny, Annette. 1975. The Lay of the Land: Metaphor As Experience and History in American Life and Letters. Chapel Hill: University of North Carolina Press.

Kreyling, Michael. 2005. The Novels of Ross Macdonald. Columbia: University of South Carolina Press.

Macdonald, Ross. 1998. "A Writer on the 1969 Santa Barbara Oil Spill, 1972." In Green Versus Gold: Sources In California's Environmental History, edited by Carolyn Merchant, 326-328. Covelo: Island Press.

—. 1973. Sleeping Beauty. New York: Knopf.

—. 2012. The Drowning Pool. London: Penguin.

—. 1971. The Underground Man. Glasgow: Collins.

Moore, Lewis D. 2006. Cracking the Hard-Boiled Detective: A Critical History from the 1920s to the Present. Jefferson: McFarland.

Nelson, Paul, and Kevin Avery. 2016. It's All One Case: The Illustrated Ross Macdonald Archives. Seattle: Fantagraphics Books.

Nolan, Tom. 1999. Ross Macdonald. New York: Scribner.

Scaggs, John. 2005. Crime Fiction. Abingdon: Routledge. 
Wagner-Martin, Linda. 2013. A History of American Literature: 1950 to the Present. Chichester: Wiley.

Weinkauf, Mary Stanley. 1994. Hard-boiled Heretic: The Lew Archer Novels of Ross Macdonald. Rockville: Wildside Press.

Willett, Ralph. 1996. The Naked City: Urban Crime Fiction in the USA. Manchester: Manchester University Press.

Witschi, Nicolas S. 2014. "Detective Fiction." In A Companion to the Literature and Culture of the American West, edited by Nicolas S. Witschi, 380-394. Chichester: Wiley. 